\title{
The Impact of The CG Scorecard on Earning Management with Firm's Characteristics as a Variable Intervening
}

\author{
*Corresponding Author \\ Rieke Pernamasari

\section{Article History} \\ Received: 04.05.2020 \\ Accepted: 11.05 .2020 \\ Published: 16.05.2020
}

Rieke Pernamasari $^{1 *}$, Giawan Nur Fitria ${ }^{1}$, Noor Hazlina Ahmad ${ }^{2}$

${ }^{1}$ Universitas Mercu Buana, Jakarta, Indonesia

${ }^{2}$ Universiti Sains Malaysia, Penang, Malaysia

\begin{abstract}
This study aims to examine the effect of the CG Scorecard on Earnings Management with company characteristics as an intervening variable. The population and sample are public companies in Indonesia and Malaysia listed on the Asean Star Index, 2016-2018. CG Scorecard is measured using the ASEAN Score Card, earnings management is measured based on the accrual of working capital to sales while intervening variables are measured using company characteristics through leverage. The analysis model is the Structural Equation Modeling Partial Least Square (SEM - PLS). The results showed that the direct relationship between GCG variables with earnings management is smaller than the relationship between GCG and earnings management through leverage variables. These results conclude that although in the short term investors do not really value the leverage rate as an investment indicator, if high debt comes from capital and continues to increase, it can be used as a signal for principals because it can be indicated earnings management actions occur. Therefore good corporate governance is one factor that can reduce agency conflict, thereby minimizing earnings management actions.
\end{abstract}

Keywords: CG Scorecard, DER, Earning Management.

\section{INTRODUCTION}

Announcement of accounting information from financial statements gives a signal that the company has good prospects in the future investors need to be interested in trading shares, thus the market will discuss what is needed through changes in stock prices. Thus, the relationship between the publication of information both financial, financial or social political conditions on fluctuations in stock prices can be seen from market efficiency [1].

Investors' decisions in investing in a company are based on various considerations, one of which is company profits. However earnings in financial statements do not necessarily reflect the situation, because there is management to manipulate earnings in order to improve performance and the company's value remains good. In accordance with the results of [2] that the practice of earnings management is mostly done by management because they consider that other companies do a lot of similar things. Conceptually, this is a strong management tool that is used to improve the welfare of corporate stakeholders if used ethically in accordance with accounting provisions [3].

One reason why earnings management is a relevant subject is a concern because income is actually used for a variety of purposes, such as contractual obligations (eg debt agreements), asset valuation and executive remuneration and bonus plans (eg executive equity compensation). Therefore [4], say accounting data provides information content that is relevant and used by various stakeholders. For example, creditors use reported numbers to assess aspects related to the company's financial health, credibility and survival of the company. So that shareholders use revenue, among other indicators, to monitor operational performance. However, their conclusions on the performance of certain entities may be wrong if they cannot identify and adjust the effects of earnings management embedded in financial statements. This distortion will become clear in future results, when the entity's performance is not in accordance with their estimates. This is believed [5] that earnings management actions at companies because they cannot be separated from various

Copyright @ 2020: This is an open-access article distributed under the terms of the Creative Commons Attribution license which permits unrestricted use, distribution, and reproduction in any medium for non commercial use (NonCommercial, or CC-BY-NC) provided the original author and source are credited. 
factors or motivations such as motivation bonuses, politics, taxes, changes in chief executive officers (CEOs), initial public offerings (IPOs), debt and motivation to meet expectations and maintain reputation. Some of the ways in which business entities are involved in managing earnings are reduction of income and reduction in income smoothing income.

Earnings management actions to be used to reduce interference from outside parties and protect personal control, for example policies in making financial statements inaccurately inaccurate about company performance [6]. In such circumstances, a manager is reasonably thought to have a great opportunity to do earnings management. The results of the study of Leuz et al., in [2] who conducted an international comparative study of earnings management in 31 countries, resulting in comparison with ASEAN countries which were selected as samples, namely: Malaysia, the Philippines and Thailand, then Indonesia is the country with the highest level of profit management, while for legal enforcement in Indonesia it is very weak and this has an impact on the low level of protection against investors.

One effort to reduce the "control rights" given by shareholders to managers is to implement good corporate governance. Investors tend to see the level of GCG implementation as an indicator of the level of risk of a company before making a funding decision. Besides being able to reduce agency problems, implementing GCG will provide trust for investors and creditors. Thus, board and management relations, must be characterized by transparency to shareholders, and justice for stakeholders. The purpose of GCG is to protect the rights of stakeholders from the takeover of managers, and the rights of insiders and controlling shareholders. CG can be used to protect the rights of all stakeholders from expropriation by managers, insiders, and controlling shareholders, through earnings management. Therefore, the presence of independent commissioners, audit committees and ownership structures in a company, are expected to carry out the supervisory function more effectively in the company, so as to minimize opportunistic actions of managers [7-10].

However, even though corporate GCG is defined equally for each company, there are large differences between corporate governance practices in the markets of developed and developing countries. This difference can be measured using the ASEAN corporate governance score card, which is a standard method of measuring corporate governance for public companies in ASEAN initiated by the ASEAN capital market forum (ACMF). This ACMF has a goal so that companies in ASEAN will realize the importance of corporate governance for each company, Andrea et al., in [11].

In addition to GCG factors, other factors that can be seen for earnings management behavior are through company characteristics, one of which is leverage. Besides being defined as the company's ability to use assets or funds that have been set up to increase the level of income for company owners, leverage is also used to determine the amount of financial [12].

Resources needed to consider the composition of financial companies that aim to increase profits. Research Sweeney, 1994; Dichev \& Skinner, 2002 and Beatty \& Weber, 2003 in [13] resulted in leverage increasing the potential for earnings management to respond to avoiding violations of debt agreements. For example, Sweeney in his research provides direct evidence of the greater the debt to company capital ratio, the more likely the company manager to do so select an accounting procedure to increase income. Measures the leverage relationship on earnings management concludes that increased debt can reduce managerial discretionary expenditure and in turn reduce accrual earnings management [14].

\section{LITERATURE}

\section{Agency Theory}

Agency theory states that there is an agency relationship as a contract between management as an agent and ownership as a corporate preliminary, a working relationship between the party that gives authority (preliminary), namely the shareholders and the recipient authority (agent) of the company in the form of cooperation, called the nexus of contract preliminary giving authority and authority to the agent to run the company in the interests of the owner and capital [15]. The agent has more information about his capacity, work environment and the company as a whole. This has resulted in an imbalance of information between the principal and the agent, which is called information asymmetry. This information asymmetry and conflict of interest encourage agents to present false information to the principal, especially if the information is related to the agent's performance.

\section{Earnings Management}

earnings management as "equal ability to increase or decrease reported net income at will", this means that earnings management includes management's efforts to maximize or minimize earnings including earnings equipment in accordance with management's wishes. Earnings management is done to influence investors' perceptions, especially to influence the company's stock buying decisions. Further [16] revealed several techniques that can be used to manipulate real activities, including sales manipulation, overproduction, and reducing the cost of discretion. With the tendency of managers to seek their own benefits (moral hazard) and a high level of information asymmetry, plus certain motives, 
increasing the possibility of management utilizing accrual items to present profits in accordance with management interests that may not be in accordance with the interests of principals, such as owner, shareholder, or lender.

To find out whether there is earnings management [2], disclose the measurement of accruals is very important to note. Total accruals is the difference between earnings and cash flows from operating activities. Total accruals can be divided into two parts, namely (1) the part that naturally exists in the process of preparing financial statements and (2) the accrual part which is a manipulation of accounting data called abnormal accruals.

\section{Corporate governance}

Corporate governance refers to the system through which the behavior of a company is monitored and controlled. The significance of corporate governance is that, in modern economies, large corporations are typically associated with a division of labor between the parties who provide the capital (shareholders) and the parties who manage the resources (management). Various studies have been carried out in relation to corporate governance mechanisms serving to minimize earnings management practices. Some of these studies show the components of corporate governance, such as composition of the independent board of commissioner, the existence of audit committee, the duality of roles, ownership structure, reduce earnings management $[11,17,18,10,19,20,8]$.

\section{Leverage as Firm's Characteristics}

The leverage ratio describes the source of operating funds used by the company. The leverage ratio also shows the risks faced by the company. The greater the risk faced by the company, the uncertainty to generate profits in the future will also increase [21]. The consequences of using leverage according to [22] is if the use of debt turns out the rate of return on assets (return) is greater than the cost of debt, the leverage is profitable and the return on capital with the use of this leverage also increases, conversely if the return on assets is smaller than the cost of debt, the leverage will reduce rate of return on capital.

\section{METHODS}

Population and Sample

Population is a group of objects that have certain qualities and characteristics determined by researchers to be studied and then drawn conclusions in a specific research [23]. The population of this research is Indonesian and Malaysian public companies registered in the ASEAN Star 2016 - 2018.

The sampling technique used in this study is the purposive sampling method, where the sample is chosen based on the suitability of the characteristics with the criteria (consideration) of the sample determined to obtain a representative sample. The sample of this research is 12 companies multiplied by 2 countries (Indonesia and Malaysia), multiplied by the number of years of observation, so that the total sample is 72 data.

\section{Variables \\ Independent variable}

Independent variables or free variables are types of variables that affect the dependent variable. The free variable used in this study is the CG Scorecard which is measured by using the ASEAN Score Card which is broken down into five indicators of corporate governance, namely: right of shareholders, equitable treatment of shareholders, role of stakeholders, disclosure and transparency, and responsibilities of the board.

\section{Dependent Variable}

Dependent variable or dependent variable is a variable that is the main concern of the researcher. The dependent variable in this study is Profit Management which is measured by the ratio of accruals of working capital to sales [2].

Earning Management $(E M)=$ working capital accruals $(\mathrm{t}) /$ Sales period $(\mathrm{t})$

Working capital accruals $=\Delta \mathrm{AL}-\Delta \mathrm{HL}-\Delta \mathrm{Cash}$

$\Delta \mathrm{AL}=$ changes in current assets in the period $\mathrm{t}$

$\Delta \mathrm{HL}=$ changes in current debt in the period $\mathrm{t}$

$\Delta \mathrm{Cash}=$ cash changes and cash equivalents in the period $\mathrm{t}$

\section{Intervening variable}

Variables that theoretically influence the relationship between the dependent independent variables. In this study leverage variable as an intervening variable is measured through the ratio of debt to equity.

Debt to Equity Ratio = Total Debt / Equity 


\section{Model and Analysis Techniques}

The analytical method used is a quantitative method, which is a data processing approach through statistical or mathematical methods collected from secondary data. It is expected that the conclusions obtained in a study are more measurable and comprehensive. The data were analyzed using the Structural Equation Modeling Partial Least Square (SEM - PLS).

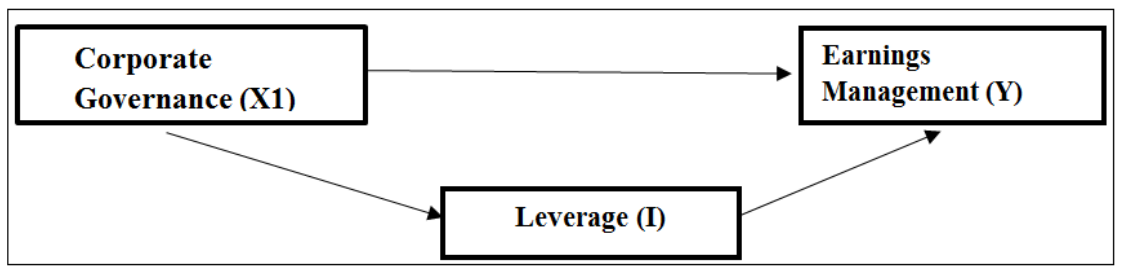

Fig-1: Conceptual Framework

\section{RESUlTS AND DiSCUSSION}

Table-1: Descriptive Test Results

\begin{tabular}{|l|l|l|l|}
\hline Countries & GCG Score (Mean) & Leverage (Mean) & Earning Management (Mean) \\
\hline Indonesia & 67.1507 & .899 & -.04354373476824 \\
\hline Malaysia & 89.4341 & 1.99659721649799 & -.04744198137903 \\
\hline \multicolumn{4}{|c|}{ Sumber: SPSS.22 } \\
\hline
\end{tabular}

In the descriptive statistical analysis table obtained can be described as follows:

1. In determining corporate governance scores there are 2 levels of assessment found on the ASEAN CG Scorecard. Level 1 consists of 5 main sections in accordance with OECD governance principles, including the right of shareholders, equitable treatment, the role of stakeholders, disclosure and transparency, and responsibility of the board. While level 2 consists of 2 additional sections, namely bonus and penalty. Bonuses are given if the company does things that exceed the standard limit and penalties are given if the company does corporate governance that is not appropriate or lacking in standards. GCG scores of public companies in Indonesia have a mean value of 67.15 and Malaysia have a mean value of 89.43 . This means that both directly and indirectly companies in Indonesia and Malaysia that are members of FTSE have implemented the principles of good corporate governance, where the corporate governance framework has protected the rights of shareholders including minority and foreign shareholders, encouraging active cooperation between companies with stakeholders, disclose in a timely manner all material ranging from the financial situation, performance, ownership and corporate governance, and effective management monitoring by the board.

2. The characteristics of the company represented through DER has a mean value of $-89.9 \%$ for Indonesia companies and has means value of $199.65 \%$ for Malaysia. On average the consumption sector manufacturing companies have a value of $58 \%$, this means that companies use more equity to fund the needs of the company

3. Earnings management is the company's manager's efforts to intervene or influence information in financial statements. Obtained Indonesia have mean value of $-4,3 \%$ and Malaysia have means value of $-4.7 \%$. This means that management both companies has influencing the company's operations.

\section{Evaluation of Measurement Model}

In this study, hypothesis testing using the Partial Least Square (PLS) analysis technique with the following SmartPLS 3.0 program is the result of the PLS program model scheme tested:

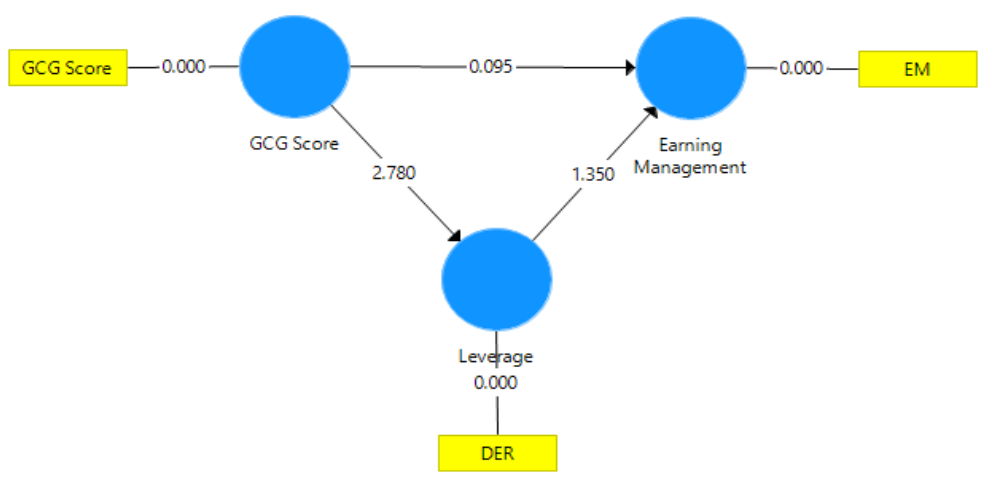

Fig-2: Loading Factor 
The loading factor illustrates how big the indicators are related to each construct. The path diagram above shows that all indicators have a loading factor of 1,000, which means that all indicators are valid because the loading factor meets the criteria, it the loading factor of the contract must be above 0.70 . These results indicate a good relationship between the indicators with each construct.

The second check of convergent validity is to look at the value of Cronbach's alpha and composite reliability. The result is as follows:

Table-2: Construct Reliability and Validity

\begin{tabular}{|l|r|r|r|}
\hline & Cronbach's Alpha & Composite Reliability & Average Variance Extracted (AVE) \\
\hline EM & 1.000 & 1.000 & 1.000 \\
\hline DER & 1.000 & 1.000 & 1.000 \\
\hline GCG & 1.000 & 1.000 & 1.000 \\
\hline
\end{tabular}

Source: Data processing Smart PLS 3.0

Cronbachs alpha values and composite reliability above 0.7 indicate high reliability of measuring instruments, which means that the gauges of each construct are highly correlated. The third check of convergent validity is to look at the value of AVE. AVE values above 0.5 are highly recommended. From table 4 all contracts are 1 or above 0.5 .

\section{Evaluation of Structural Models}

After the inspection of the measurement model is fulfilled, then the next is the examination of the structural model. This examination includes the significance of the path relationship and the value of $\mathrm{R}$ Square (R2) to see the results of the structural model evaluation. The value of $\mathrm{R} 2$ aims to find out how much the independent variable influences the dependent variable. The value of R2 can be seen from the following table:

Table-3: R Square

\begin{tabular}{|l|r|r|r|r|}
\hline & \multicolumn{3}{|c|}{ Earning Management } & Leverage \\
\hline & R Square & R Square Adjusted & R Square & R Square Adjusted \\
\hline Indonesia & 0.585 & 0.560 & 0.016 & 0.560 \\
\hline Malaysia & 0.068 & -0.040 & 0.020 & -0.040 \\
\hline Indonesia and Malaysian & 0.044 & 0.017 & 0.028 & 0.014 \\
\hline
\end{tabular}

Source: Data processing Smart PLS 3.0

Indonesia have value of Earning management is 0.585 , its means that the Earning Management construct variability can be explained by the GCG and Leverage variable of $58.6 \%$ and the rest is influenced by other variables outside the study. While the DER construct can be explained by the GCG variable of $1 \%$.

Malaysia have value of Earning management is 0.068 , its means that the Earning Management construct variability can be explained by the GCG and Leverage variable of $6.8 \%$ and the rest is influenced by other variables outside the study. While the DER construct can be explained by the GCG variable of $2 \%$.

\section{Hypothesis Test Results}

Table-4: Path Coefficient Value (Original sample, T-Values, P-Values)

\begin{tabular}{|l|c|c|c|r|r|r|r|r|r|}
\hline & \multicolumn{3}{|c|}{ GCG -> EM } & \multicolumn{2}{c|}{ GCG -> Leverage } & \multicolumn{2}{c|}{ Leverage -> EM } \\
\cline { 2 - 10 } & $\begin{array}{c}\text { Original } \\
\text { Sample } \\
(\mathrm{O})\end{array}$ & $\begin{array}{c}\mathrm{T} \\
\text { Statistics }\end{array}$ & $\begin{array}{c}\mathrm{P} \\
\text { Values }\end{array}$ & $\begin{array}{c}\text { Original } \\
\text { Sample } \\
(\mathrm{O})\end{array}$ & $\begin{array}{c}\mathrm{T} \\
\text { Statistics }\end{array}$ & $\begin{array}{c}\mathrm{P} \\
\text { Values }\end{array}$ & $\begin{array}{c}\text { Original } \\
\text { Sample } \\
(\mathrm{O})\end{array}$ & $\begin{array}{c}\mathrm{T} \\
\text { Statistics }\end{array}$ & $\begin{array}{c}\mathrm{P} \\
\text { Values }\end{array}$ \\
\hline Indonesia & -0.055 & 0.546 & 0.585 & 0.26 & 2.045 & 0.041 & -0.749 & 3.146 & 0.002 \\
\hline Malaysia & 0.119 & 0.617 & 0.538 & -0.14 & 1.142 & 0.254 & -0.025 & 0.189 & 0.85 \\
\hline $\begin{array}{l}\text { Indonesia } \\
\text { and } \\
\text { Malaysia }\end{array}$ & -0.009 & 0.095 & 0.924 & 0.166 & 2.78 & 0.006 & -0.209 & 0.35 & 0.178 \\
\hline
\end{tabular}

Source: Data processing Smart PLS 3.0

Based on the above table, the results can be used to answer the hypotheses in this study. Hypothesis testing in this study is done by looking at the T-Statistic value and the PValue value, it can be seen that the test of the relationship between constructs shows that all constructs are positively related significantly can affect stock prices with a $\mathrm{T}$ value> 1.96 and a $\mathrm{P}$ value $<0.05$. So it can be concluded that untuk data perusahaan Indonesia, GCG tidak memiliki pengaruh 
secara langsung terhadap earning management, namun GCG memiliki pengaruh positif terhadap leverage dan leverage memiliki pengaruh negative terhadap earning management. Sedangkan pad aperusahaan Malaysia, GCG tidak memiliki pengaruh secara langsung terhadap earning management namun GCG memiliki pengaruh positif terhadap leverage akan tetapi leverage tidak memiliki pengaruh terhadap earning management. Dari kedua Negara tersebut dapat disimpulkan bahwa hubungan GCG secara langsung terhadap earning management memiliki nilai yag lebih kecil dibandingkan hubungan antara GCG terhadap leverage dan leverage terhadap earning management. by comparing the two values, it can be proven that the GCG variable on earnings management is directly smaller than the effect of the GCG variable on earnings management through DER. So it can be concluded that DER is able to be an intervening variable between GCG and earnings management.

\section{Analysis Result}

\section{The effect of corporate governance to leverage}

Hypothesis test results untuk perusahaan di Indonesia dan di Malaysia show that CG Score has significant positive effect on leverage measured through DER on public companies in Indonesia that are registered in the ASEAN Star group. These results conclude that the company has a high debt from investors as capital, which is able to increase the level of risk of the company. However, a positive value in the table can be said that investors believe in the company because this ting can be a positive signal for investors, if supervision in the company is good then investors believe that the company is able to manage debt.

These results are in line with research [24], in another perspective, a higher DER is a positive signal for investors, if supervision in the company is good at managing debt, the return on capital using leverage also increases, conversely if the return on assets is less than the cost of debt, then leverage will reduce the rate of return on capital..

\section{The effect of leverage to earnings management}

Hypothesis test results indicate that untuk perusahaan di Indonesia the leverage measured through DER has an significant negative effect on earnings management. Sedangkan pada perusahaan Malaysia leverage yang diukur melalui DER has an insignificant negative effect on earning management. These results conclude that a high level of DER causes the level of company dependence on external parties is also high and the greater the burden of debt to be paid by the company. This means that earnings management actions cannot be used as a mechanism to avoid this risk in the short term, because the fulfillment of obligations must still be done by the company and cannot be avoided anymore. But in the long run if debt will continue to grow, it can be a tool for management to take earnings management actions. In accordance with agency theory, management needs to meet the needs of the principal. but the more money spent the company the more stringent supervision conducted by creditors, so that management to manage earnings decreases. This result can also be caused by public companies listed in ASEAN stars which are dominated by state-owned companies.

In accordance with research $[14,25]$ the average company has a safe leverage in the sense that the company is able to pay the debt used to finance the company's assets, so managers are not interested or motivated to practice earnings management. The company does not need actions that will help the company in certain situations. The company is in a good or safe condition and is able to repay debts that are used to finance the company's assets.

\section{The effect of corporate governance to earnings management}

Based on the results of hypothesis testing untuk perusahaan di Indonesia dan di Malaysia shows that CG scores have a insignificant negative effect on earnings management in public companies in Malaysia and Indonesia that are registered in the ASEAN Star group. These results indicate that the GCG score measures consisting of right of shareholders, equitable treatment of shareholders, role of stakeholders, disclosure and transparency, and responsibilities of the board are considered to have no effect on earnings management because they have significant values above> 0.05 . Although according to [26] research that the activities of the board of directors and audit committee are important factors in inhibiting the tendency of managers involved in earnings management. But for investors the responsibility of directors has a relationship in how to manage the company so that it earns profits and benefits investors. However, indirectly with good corporate governance is able to suppress management actions to provide incorrect information to shareholders.

These results are consistent with the study [5, 27]. The implementation of corporate governance proves in limiting the tendency of management to manage earnings and actually direct the presentation of financial statements with high credibility. The application of GCG is able to reduce the management of companies conducting earnings management practices through income discretion even though the results show there are still gaps and opportunities for earnings management through real activities.

\section{The effect of corporate governance to earnings management with leverage as variable intervening}

Hypothesis test results show that the direct relationship between GCG variables and earnings management is smaller than the relationship between GCG and earnings management through DER. These results conclude that although 
in the short term investors do not really value the leverage rate as an investment indicator, if high debt comes from capital and continues to increase, it can be used as a signal for principals because it can be indicated earnings management actions occur. Therefore good corporate governance is one factor that can reduce agency conflict, thereby minimizing earnings management actions.

In accordance with research [28] companies with good corporate governance tend to do less earnings management and companies with high leverage with poor governance tend to be scrutinized carefully and therefore it is more difficult to fool the market by manipulating revenue.

\section{CONCLUSIONS}

The direct effect of GCG on earnings management is smaller than the effect of GCG on earnings management through leverage variables. In the long run if debt originating from investor capital continues to increase, it can be used as a signal for principals to increase the level of oversight of management activities. The application of corporate governance has been proven to limit management's tendency to manage revenue and actually direct the presentation of financial statements with high credibility.

\section{SUGGEST}

Companies must embrace an established corporate governance structure that will assist them in reducing financial statement fraud. Investors can make Asian priorities especially for countries that have presented GCG indexes for investment. It is hoped that the next research can be carried out in all ASEAN countries by adding research years.

\section{REFERENCES}

1. Irama, O. N. (2018). Pengaruh Potensi Kebangkrutan Terhadap Harga Saham Pada Perusahaan Manufaktur Yang Terdaftar Di Bursa Efek Indonesia. Jurnal Bisnis Net, 1(1), 219-226.

2. Utami, W. (2005). Pengaruh manajemen laba terhadap biaya modal ekuitas (studi pada perusahaan publik sektor manufaktur). SNA VIII Solo 15-16 September 2005, 100-116.

3. Omar, N., Rahman, R. A., Danbatta, B. L., \& Sulaiman, S. (2014). Management Disclosure and Earnings Management Practices in Reducing the Implication Risk. Procedia - Social and Behavioral Sciences, 145, 88-96. https://doi.org/10.1016/j.sbspro.2014.06.014

4. Cupertino, C. M., Martinez, A. L., \& da Costa, N. C. A. (2015). Earnings manipulations by real activities management and investors' perceptions. Research in International Business and Finance, 34, 309-323. https://doi.org/10.1016/j.ribaf.2015.02.015

5. Muda, I., Maulana, W., Siregar, H. S., \& Indra, N. (2018). The analysis of effects of good corporate governance on earnings management in Indonesia with panel data approach. Iranian Economic Review, 22(2), 599-625. https://doi.org/10.22059/ier.2018.66169

6. Shen, C. H., \& Chih, H. L. (2007). Earnings management and corporate governance in Asia's emerging markets. Corporate Governance: An International Review, 15(5), 999-1021. https://doi.org/10.1111/j.14678683.2007.00624.x

7. Pernamasari, R. (2018). The Effect Of Accrual Earnings, Corporate Governance, and Firm Size On Earnings Persistence Of 100 Compass Index Companies Listed 2015-2016. 9(10), 196-205.

8. Surifah. (2017). The Role Of Corporate Governance In The Effect Earnings Management Has On Firm Value. Journal of Indonesian Economy and Business, 32(1), 51-69.

9. Turnbull, C.S.H. (2000). Corporate Governance: Theories, Challenges and Paradigms. SSRN Electronic Journal, 1(1), 11-43. https://doi.org/10.2139/ssrn.221350.

10. Gumanti, T. A., Nastiti, A. S., \& Lestari, A. R. (2016). Good corporate governance and earnings management in indonesian initial public offerings. Corporate Ownership and Control, 13(4), 558-565. https://doi.org/10.22495/cocv13i4c4p5

11. Ugbede, O., Lizam, M., \& Kaseri, A. (2013). Corporate governance and earnings management: Empirical evidence from Malaysian and Nigerian banks. Asian Journal of Management Sciences \& Education, 2(4), 1-21. Retrieved from http://www.leena-luna.co.jp/

12. Veronica, A. (2015). The Influence of Leverage and Its Size on the Earnings Management. Research Journal of Finance and Accounting, 6(8), 159-167. https://doi.org/10.1016/s0016-5085(12)61792-2

13. Zamri, N., Rahman, R. A., \& Isa, N. S. M. (2013). The Impact of Leverage on Real Earnings Management. Procedia Economics and Finance, 7, 86-95. https://doi.org/10.1016/s2212-5671(13)00222-0

14. Ardison, M. M. K., Martinez, A. L., \& Galdi, F. C. (2012). The effect of leverage on earnings management in Brazil. Advances in Scientific and Applied Accounting, (September), $305-324$. https://doi.org/10.14392/asaa/2012050301

15. Jensen, M. C., \& Meckling, W. H. (1976). Theory of the firm: managerial behavior, agency costs and ownership 
structure. Journal of Financial Economics, 3(4), 305-360. https://doi.org/10.1002/mde.1218

16. Roychowdhury, S. (2006). Earnings management through real activities manipulation. Journal of Accounting and Economics, 42(3), 335-370. https://doi.org/10.1016/j.jacceco.2006.01.002

17. Mansor, N., Che-Ahmad, A., Ahmad-Zaluki, N. A., \& Osman, A. H. (2013). Corporate Governance and Earnings Management: A Study on the Malaysian Family and Non-family Owned PLCs. Procedia Economics and Finance, 7(August 2014), 221-229. https://doi.org/10.1016/s2212-5671(13)00238-4

18. Sasaninejad, Y., Madrakian, H., \& Khodabakhsh, A. (2014). Investigating the Relationship between Corporate Governance Ranking and Earnings Management in Companies Listed in Tehran Stock Exchange. Kuwait Chapter of Arabian Journal of Business and Management Review, 3(12), 302-309. https://doi.org/10.12816/0018835

19. Cupertino, C. M., Martinez, A. L., \& da Costa, N. C. A. (2015). Earnings manipulations by real activities management and investors' perceptions. Research in International Business and Finance, 34, 309-323. https://doi.org/10.1016/j.ribaf.2015.02.015

20. Laily, N. (2017). The Effects of Good Corporate Governance and Audit Quality on Earnings Management. Journal of Accounting and Business Education, 1(1), 134. https://doi.org/10.26675/jabe.v1i1.9754

21. Agustia, D. (2013). Pengaruh Faktor Good Corporate Governance, Free Cash Flow, dan Leverage Terhadap Manajemen Laba. Jurnal Akuntansi Dan Keuangan, 15(1), 27-42. https://doi.org/10.9744/jak.15.1.27-42

22. Cai, J., \& Zhang, Z. (2011). Leverage Change, Debt Capacity, and Stock Prices. SSRN Electronic Journal, (April). https://doi.org/10.2139/ssrn.1107878

23. Sugiyono. (2013). Metode Penelitian Kuantitatif, Kualitatif, dan R\&D. Bandung: Alfabeta.

24. Utami, W., \& Pernamasari, R. (2019). Study on asean listed companies: corporate governance and firm performance. International Journal of Business, Economics and Law, 19(5), 181-188.

25. Dimarcia, N., \& Krisnadewi, K. (2016). Pengaruh Diversifikasi Operasi, Leverage Dan Kepemilikan Manajerial Pada Manajemen Laba. E-Jurnal Akuntansi, 15(3), 2324-2351.

26. Xie, B., Davidson III, W. N., \& DaDalt, P. J. (2003). Earnings management and corporate governance: the role of the board and the audit committee. Journal of corporate finance, 9(3), 295-316.

27. Istianingsih, I. (2017). Deteksi Manajemen Laba Melalui Discretionary Revenue Dan Aktifitas Riil: Implikasi Penerapan Good Corporate Governance. Jurnal Riset Akuntansi Dan Keuangan, 4(3), 1125-1142. https://doi.org/10.17509/jrak.v4i3.4666

28. Shen, C. H., \& Chih, H. L. (2007). Earnings management and corporate governance in Asia's emerging markets. Corporate Governance: An International Review, 15(5),999-1021. 